\title{
Natural Contaminants in Drinking Waters (Arsenic, Boron, Fluorine and Vanadium) in the Southern Pampean Plain, Argentina
}

\author{
Martín E. Espósito ${ }^{1}$, Juan D. Paoloni ${ }^{4}$, Mario E. Sequeira ${ }^{2,3}$, Nilda M. Amiottii ${ }^{1,3}$, María del C. Blanco ${ }^{1}$ \\ ${ }^{1}$ Epto. de Agronomía-UNS; ${ }^{2}$ Depto. de Ingeniería-UNS; ${ }^{3}$ CERZOS-CONICET; ${ }^{4}$ CONICET. \\ Email:mesposito@uns.edu.ar,namiotti@criba.edu.ar, mcblanco@criba.edu.ar, sequeira@criba.edu.ar,jpaoloni@criba.edu.ar
}

Received October $14^{\text {th }}, 2010$; revised November $19^{\text {th }}, 2010$; accepted December $28^{\text {th }}, 2010$

\begin{abstract}
This research aims at making a diagnosis of the presence of arsenic, boron, fluorine and vanadium in the waters from the basin of El Divisorio stream, tributary of Paso de las Piedras reservoir, in the southwest of Buenos Aires Province. This storage is used to provide water to the cities of Bahía Blanca and Punta Alta with a population of approximately 400,000 inhabitants. A selective and specific sampling of wells, perforations and superficial watercourses was made in 46 points, in an area of nearly $400 \mathrm{~km}^{2}$. Groundwaters had arsenic (max. $0.114 \mathrm{mg} / \mathrm{l}$ ) exceeding the reference guideline in 97.3\% of the samples, boron ( $\max .1 .42 \mathrm{mg} / \mathrm{l}$ ), vanadium ( $\max .0 .8 \mathrm{mg} / \mathrm{l}$ ) and fluorine ( $\mathrm{max} .6 .6 \mathrm{mg} / \mathrm{l}$ ), being respecttively, 91.9\%, 82.9\%, and 67.6\%. Regarding the superficial flow, while arsenic concentrations were higher than the limit in 100\% of the cases (max. $0.072 \mathrm{mg} / \mathrm{l}$ ), 88.9\% corresponded to elevated boron (max. $1 \mathrm{mg} / \mathrm{l}$ ) and vanadium (max. $0.23 \mathrm{mg} / \mathrm{l}$ ) and only 22.2\% to fluorine ( $\mathrm{max} .3 .18 \mathrm{mg} / \mathrm{l}$ ) ones. In all these cases, concentrations exceed the reference guideline values suggested by the World Health Organization, the Argentine Food Code and the Environmental Protection Agency. The presence of these contaminants that finally could determine the quality of the water resource entering the reservoir is attributed to the natural characteristics of the environment since contributions by anthropic actions have not been detected in the area. The most critical sectors in the basin were identified in order to stress the possible negative influence of consuming these waters on the community's health, with the purpose of reporting the results to institutions, authorities and the population and applying them to preventive medicine.
\end{abstract}

Keywords: Arsenic, Fluorine, Vanadium, Hydrochemistry, Risk

\section{Introduction}

The continuous demographic growth and the increase of food production boosted by technology have intensified the pressure on water usage for producing food, goods and services. Because of this, the rising demand of groundwater has grown exponentially alongside problems regarding the availability and quality of the provision sources and risks posed for human health [1].

Groundwaters are becoming an increasingly scarce resource for humanity. In addition, water quality is impaired by the presence of natural contaminants derived from the contact of water with weathered materials that compose the crust of the Earth, thus raising ion levels in water. This situation affects millions of people around the world and represents a real threat to health.

Among the most relevant natural contaminants due to their toxicity and dangerousness are arsenic, boron, fluorine and vanadium, which reduce the quality of the water resource, especially when their concentrations are higher than the reference guideline values [2-4].

The most significant consequence of a chronic exposure to arsenic (As) is the occurrence of carcinogenic pathologies in different soft organs such as the skin, lungs, pancreas and intestine $[5,6]$ as well as disorders of the nervous system [7]. In Argentina, this syndrome is known as Regional Chronic Hydroarsenicism (HACRE, for its Spanish acronym) [8]. The coexistence of the As ion with other elements present in water like boron, fluorine, vanadium and other ones [9] increases the degree of severity of the condition.

Boron (B) is an important micronutrient for superior plants [10]. In 2003, both the Subsecretaría de Recursos Hídricos de la Nación (National Office of the Under- 
Secretary for Water Resources) [11], in its guideline of water quality for human consumption, and the World Health Organization (WHO) specified that different studies in laboratory animals had evidenced several toxic effects of the oral exposure to boron such as testicular atrophy, spermatogenesis disorders and decrease of body mass, among others. According to available information and due to the lack of evidence on human carcinogenesis, the Environmental Protection Agency (US EPA) (1994) classified boron in group D, which corresponds to substances that cannot be classified as carcinogens.

Fluorine $(\mathrm{F})$ is a microcomponent that can accumulate in human beings, plants and animals [12]. The ingestion of water with high levels of $\mathrm{F}$ may lead to an increase in its total content, particularly in calcified tissues; its soluble forms may also be absorbed through the gastrointestinal tract $[2,13]$; and, in even more acute cases, it can cause different types of cancer [14]. When F concentrations in water are approximately $1.2 \mathrm{mg} / \mathrm{l}$, the first symptoms of dental fluorosis may appear $[15,16]$.

In nature, vanadium (V) participates in chlorophyll synthesis in photosynthetic organisms and it is a micronutrient for several marine and terrestrial species $[17,18]$. Water consumption is one of the routes of entry into the human body, where vanadium is absorbed and transported to several tissues through the blood stream [19] and accumulates in the liver, kidneys, bones, lungs, etc. $[20,21]$. Vanadium is a carcinogenic compound with mutagenic and genotoxic properties for the human being when it is present in high concentrations in drinking water and periods of exposure are long [22,23].

The presence of arsenic and other trace elements in superficial and groundwaters could be associated to the presence of glass, volcanic ash and other minerals As-bearers in the loess sediments, interfering in the hydrochemical characteristics [24-28].

The WHO (1995) suggests as guideline values that concentrations of arsenic, fluorine and boron for human consumption should not exceed the contents of $0.01,1.5$ and $0.3 \mathrm{mg} / \mathrm{l}$ respectively. For its part, the Argentine Food Code (3) coincides with the limit established for arsenic; as for fluorides, it recommends a table where tolerance values vary according to water temperature; and finally it differs on the value for boron, raising the level to $0.5 \mathrm{mg} / \mathrm{l}$. Regarding the limit of vanadium, the value of $0.05 \mathrm{mg} / \mathrm{l}$ proposed by the US EPA was considered.

In the southwest of Buenos Aires Province, there is precedent of contaminated superficial and groundwaters with simultaneous high levels of arsenic, boron, fluorine and vanadium which greatly exceed the values established by the different abovementioned entities, being the groundwater resource one of the main provision sources for human consumption and agricultural and farming uses. Because of this, our research work carried out in El Divisorio stream, tributary of Paso de las Piedras reservoir, in Buenos Aires Province, is aimed at making a diagnosis of the presence of these elements, identifying the most critical areas in the study region and reporting on their negative influence on human health. In addition, our study is intended to provide health care systems with information that can be applied to preventive medicine.

\section{Materials and Methods}

This research work was conducted in the endorheic basin of El Divisorio river (Figure 1), located in the hilly system corresponding to the Sierras Australes hill range, in the south of Buenos Aires Province [29]. The main watercourse drains the western slope of Pillahuincó hill, chain which corresponds to the westernmost separation of Ventania system [30]. The surface of the basin is approximately $400 \mathrm{~km}^{2}$, its bed has an extension of $40 \mathrm{~km}$ and it flows into Paso de las Piedras reservoir $\left(61^{\circ} 45^{\prime \prime} \mathrm{W}\right.$ and $38^{\circ} 25^{\prime \prime} \mathrm{S}$ ), water storage provides drinking water to Punta Alta and Bahía Blanca cities and Bahía Blanca's Petrochemical Complex [31].

The system that constitutes the basin corresponds to a seasonal rainfall pattern, the annual average being approximately $750 \mathrm{~mm}$ [32]. The mean temperature in the coldest month (July) is $7^{\circ} \mathrm{C}$ and in the hottest month (January), $23.5^{\circ} \mathrm{C}$. Winds are irregular in their direction and speed.

The main productive activities in this area are agriculture and farming, which determine a strong presence of a residing and stable rural population [33]. The area and its surroundings also have several tourism development centres which gave recently acquired significance at the local, provincial and national levels.

Maps of the Instituto Geográfico Militar (Military Geographical Institute) in scales of 1:50 000 and 1:100 000 with their respective mosaic photographs and satellite images, as well as the field survey, were used to determine the study area and demarcate the geographical location in the corresponding cartography. The heights above sea level of the sampling points were established using the Global Positioning System (GPS) Garmin etrex vista HCx.

In order to study water quality, a selective and specific sampling was conducted in the winter of 2008 in 46 points among wells, perforations and superficial watercourses used for exploiting the resource within the study area (Figure 1). Groundwater extraction was carried out in 37 points by means of traditional piston pumps, driven by wind energy (windmills), and in some cases using 

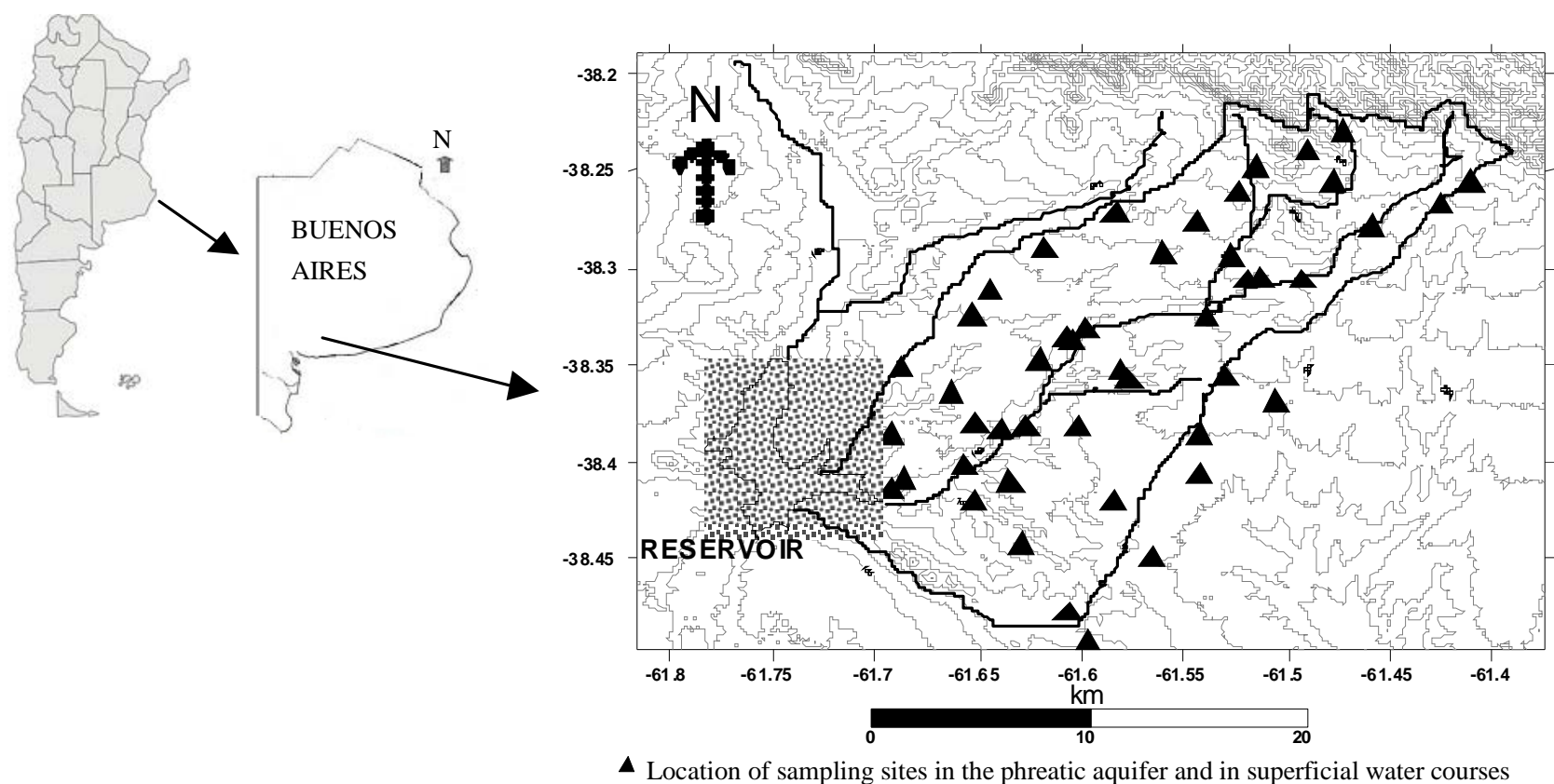

Figure 1. Geographical location of the study area and water sampling points.

electrically-driven centrifugal pumps. In wells which are discontinuously exploited, the extraction system was kept in operation during a given time so that decanted or deposited impurities did not obstruct the system. As for superficial waters, 9 samples were taken along the main watercourse and its affluents. Water samples were collected in hermetically-sealed, plastic bottles with a capacity of a half-litre volume, also labelled for identification before being placed in coolers for their later transport to the laboratory.

During water extraction, the depth of the phreatic level was determined with a Spohr probe. In all cases, water temperature was recorded and samples with replicates were collected. Quantitative determination of arsenic in waters was done by a Hydride Generator and by Inductively-Coupled Plasma and Atomic Emission Spectrometry (ICP-AES) based on Halicz and Russell's method (1986), which consists in the continuous generation of arsine $\left(\mathrm{AsH}_{3}\right)$ using three of the four channels of a peristaltic pump (Cole Palmer Instruments Company, Masterflex). The sample solution and a solution of sodium tetrahydroborate plus potassium iodide were transported to a modified liquid-gas separator. Arsine and hydrogen were collected from the separator to the plasma by a continuous flow of argon. Arsenic was determined according to its main wavelength at $193.69 \mathrm{~nm}$. Boron and vanadium were analyzed with ICP equipment and fluorine, with a specific electrode. Quality control of the chemical analyses was performed by means of ICP standard solu- tions. The treatment was supplemented with other routine analyses such as anions, cations and some trace elements.

The concentrations of arsenic, boron, fluorine and vanadium in the different sampling points which cover the area (Table 1) were used to draw thematic maps of isoconcentrations and vulnerability employing the software Surfer V. 8. On the other hand, the software InfoStat was used to perform a Principal Component Analysis (PCA) with the standardized data of the studied variables.

\section{Results}

Waters from the river courses, wells and perforations in the area are used for consumption by the stable rural population, for fulfilling farming requirements and in some cases for supplementary irrigation. No waste discharge from tanneries, mines, metallurgical plants, etc., which could be evaluated as possible contaminant sources, has been observed in the study and neighbouring areas.

Herbicides and fungicides applied as technological packages in the basin for the production of cereal crops do not contain these active ingredients. Moreover, fertilizers are used in small doses, providing only nitrogen and phosphorus. Rural farms of the basin began to adopt this technology in the last two decades as a consequence of the change underwent by production systems which caused this farming region to start turning into one more related to agricultural production. Thus, after this lapse of time the degree of anthropic contamination is not very high. 
Table 1. Concentration of arsenic, boron, fluorine and vanadium in superficial waters (grey) and groundwaters of the basin.

\begin{tabular}{|c|c|c|c|c|c|}
\hline Longitude & Latitude & $\begin{array}{c}\text { Arsenic } \\
\text { ppm }\end{array}$ & $\begin{array}{c}\text { Boron } \\
\text { ppm }\end{array}$ & $\begin{array}{c}\text { Fluorides } \\
\text { ppm }\end{array}$ & $\begin{array}{c}\text { Vanadium } \\
\text { ppm }\end{array}$ \\
\hline-61.65225 & -38.41882 & 0.068 & 1.01 & 3.93 & 0.55 \\
\hline-61.63482 & -38.40879 & 0.114 & 0.72 & 3.23 & 0.74 \\
\hline-61.62932 & -38.44197 & 0.027 & 0.93 & 0.67 & 0.27 \\
\hline-61.56575 & -38.44847 & 0.053 & 0.91 & 2.56 & 0.49 \\
\hline-61.51277 & -38.30398 & 0.031 & 0.36 & 1.05 & 0.12 \\
\hline-61.51943 & -38.30541 & 0.051 & 0.63 & 2.35 & 0.46 \\
\hline-61.52689 & -38.29328 & 0.022 & 0.33 & 0.68 & 0.10 \\
\hline-61.6071 & -38.33512 & 0.055 & 0.61 & 2.50 & 0.30 \\
\hline-61.58091 & -38.3522 & 0.083 & 0.69 & 3.24 & 0.74 \\
\hline-61.54281 & -38.38494 & 0.107 & 1.24 & 4.60 & 0.68 \\
\hline-61.54294 & -38.40554 & 0.076 & 0.97 & 2.36 & 0.66 \\
\hline-61.60184 & -38.38104 & 0.069 & 0.81 & 2.75 & 0.59 \\
\hline-61.62704 & -38.38098 & 0.032 & 0.76 & 2.28 & 0.14 \\
\hline-61.63905 & -38.38335 & 0.039 & 0.54 & 1.61 & 0.21 \\
\hline-61.59681 & -38.49197 & 0.056 & 0.89 & 2.00 & 0.54 \\
\hline-61.60647 & -38.47748 & 0.085 & 0.85 & 3.09 & 0.65 \\
\hline-61.58481 & -38.41873 & 0.099 & 1.10 & 4.40 & 0.32 \\
\hline-61.50587 & -38.36866 & 0.088 & 0.74 & 3.00 & 0.80 \\
\hline-61.53058 & -38.35495 & 0.056 & 0.84 & 3.21 & 0.24 \\
\hline-61.53935 & -38.32513 & 0.055 & 0.55 & 1.51 & 0.31 \\
\hline-61.59761 & -38.33051 & 0.072 & 0.45 & 1.18 & 0.21 \\
\hline-61.42482 & -38.267 & 0.071 & 0.31 & 0.59 & 0.15 \\
\hline-61.41075 & -38.25573 & 0.043 & 0.51 & 0.69 & 0.15 \\
\hline-61.45931 & -38.27826 & 0.013 & 0.29 & 0.66 & $<0.05$ \\
\hline-61.47797 & -38.25602 & 0.018 & 0.13 & 0.39 & 0.04 \\
\hline-61.47302 & -38.22964 & 0.026 & 0.22 & 0.4 & $<0.05$ \\
\hline-61.65167 & -38.3801 & 0.072 & 0.83 & 3.16 & 0.15 \\
\hline-61.68635 & -38.40771 & 0.054 & 0.95 & 1.73 & 0.45 \\
\hline-61.65687 & -38.40077 & 0.052 & 0.56 & 1.44 & 0.23 \\
\hline-61.52431 & -38.26066 & 0.030 & 0.67 & 1.32 & 0.19 \\
\hline-61.5154 & -38.24776 & 0.019 & 0.88 & 0.9 & 0.14 \\
\hline-61.48995 & -38.23871 & 0.010 & 0.12 & 0.2 & $<0.05$ \\
\hline-61.54416 & -38.27581 & 0.021 & 0.60 & 0.98 & 0.13 \\
\hline-61.60498 & -38.33753 & 0.024 & 0.57 & 1.13 & 0.14 \\
\hline-61.57752 & -38.3572 & 0.027 & 1.00 & 3.18 & 0.06 \\
\hline-61.64474 & -38.3111 & 0.012 & 0.60 & 1 & $<0.05$ \\
\hline-61.61879 & -38.28918 & 0.029 & 0.64 & 1.57 & 0.23 \\
\hline-61.58342 & -38.27105 & 0.026 & 0.66 & 1.24 & 0.22 \\
\hline-61.56069 & -38.29111 & 0.024 & 0.66 & 1.28 & 0.15 \\
\hline-61.6924 & -38.41359 & 0.018 & 0.51 & 0.9 & 0.07 \\
\hline-61.6628 & -38.36362 & 0.049 & 1.42 & 4.63 & 0.54 \\
\hline-61.68781 & -38.35052 & 0.056 & 0.82 & 4.86 & 0.51 \\
\hline-61.62051 & -38.34701 & 0.058 & 1.00 & 6.6 & 0.51 \\
\hline-61.65316 & -38.32424 & 0.055 & 0.82 & 4.28 & 0.50 \\
\hline-61.69243 & -38.385 & 0.036 & 1.18 & 2.04 & 0.29 \\
\hline-61.70991 & -38.42303 & 0.054 & 0.99 & 4.88 & 0.58 \\
\hline
\end{tabular}


The movement of the phreatic flow responds to characteristics typical of the basins of this hilly system, water levels in wells and perforations emphasizes variations ranging from $1.4 \mathrm{~m}$ deep at the bottoms of valleys and near beds to $41 \mathrm{~m}$ in the interfluve of the southeastern sector. The development of the phreatic surface morphology shows a significant symmetry with a significant hydraulic gradient of approximately 6.06\%o, exhibiting a substantial parallelism between the isohypses, which determines a clear orientation of the discharge towards the reservoir (Figure 2).

The presence of arsenic was detected in groundwaters in the 37 analyzed samples, 36 of which showed values higher than the established limits, being the frequency distribution of concentrations irregular and asymmetric (Figure 3) with the greatest concentration points situated in the southeastern sector of the lower basin (Figure 4). In superficial waters, the reference value was exceeded in all the samples and the highest value was found in the middle basin, not responding to a given distribution pat- tern. Making a generalization about the entire basin, arsenic concentrations found in waters widely range from $0.01 \mathrm{mg} / \mathrm{l}$ at the headwaters of the basin to $0.114 \mathrm{mg} / \mathrm{l}$ near the river mouth.

Values obtained for boron show that 34 samples of phreatic waters exceed the established limit, and also present an irregular frequency distribution (Figure 5), which demonstrates a high variability for this ion. B concentration increases downstream direction, this spatial behaviour is demonstrated by a more tight grouping of equal concentration isolines (Figure 6). In addition, maximum values are identified in locations very close to the mouth of the main watercourse, almost over the reservoir. Regarding superficial water, 8 out of the total number of samples are beyond the guideline value, located in the same sector as the high concentrations of arsenic. The minimum concentration of boron in water is $0.12 \mathrm{mg} / \mathrm{l}$ and coincides with the well where the minimum value of arsenic was found. The highest value, 1.42 $\mathrm{mg} / \mathrm{l}$, was recorded in the lower sector of the basin.

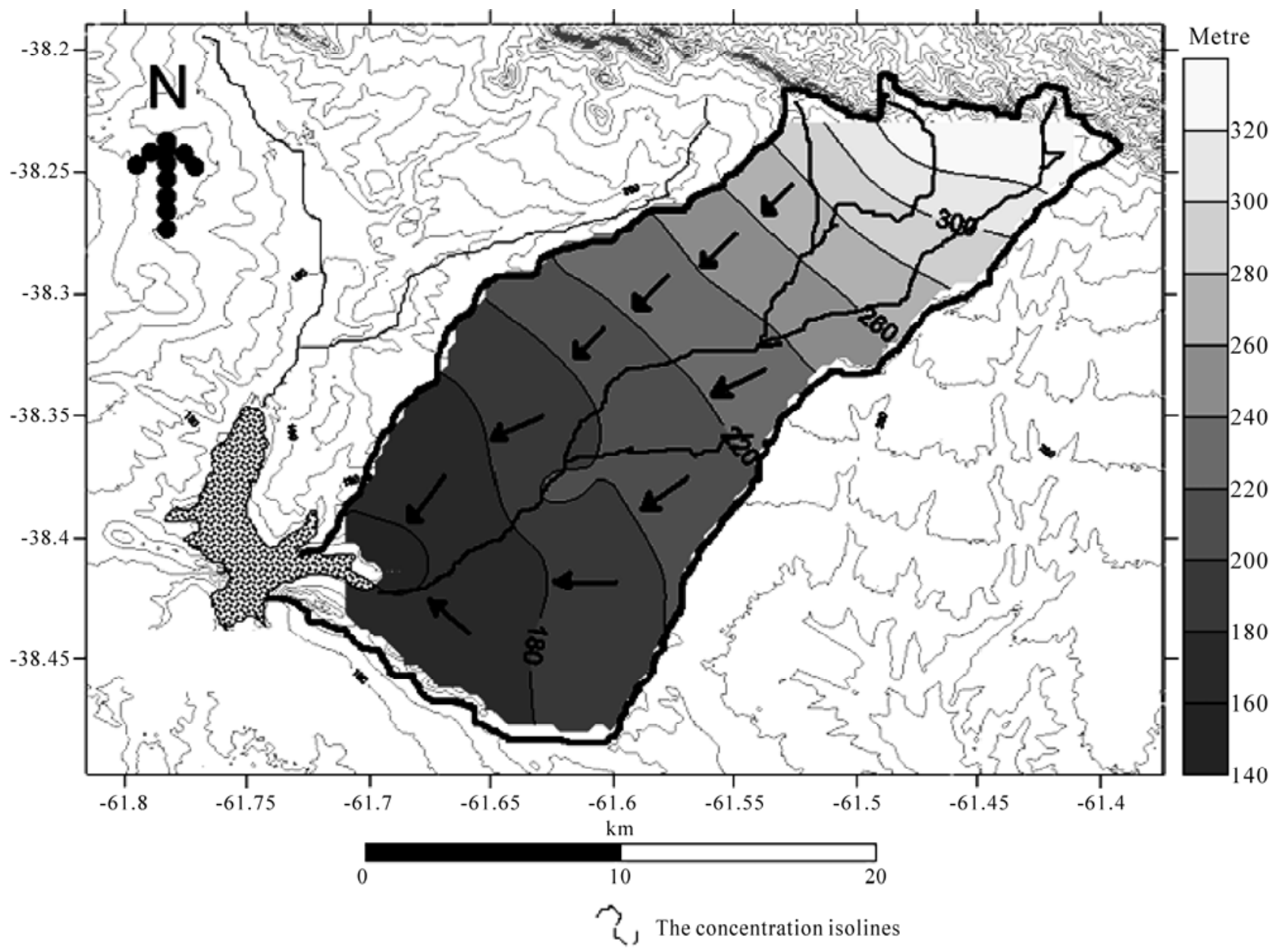

Figure 2. Map of the groundwater flow hydrodynamics. 


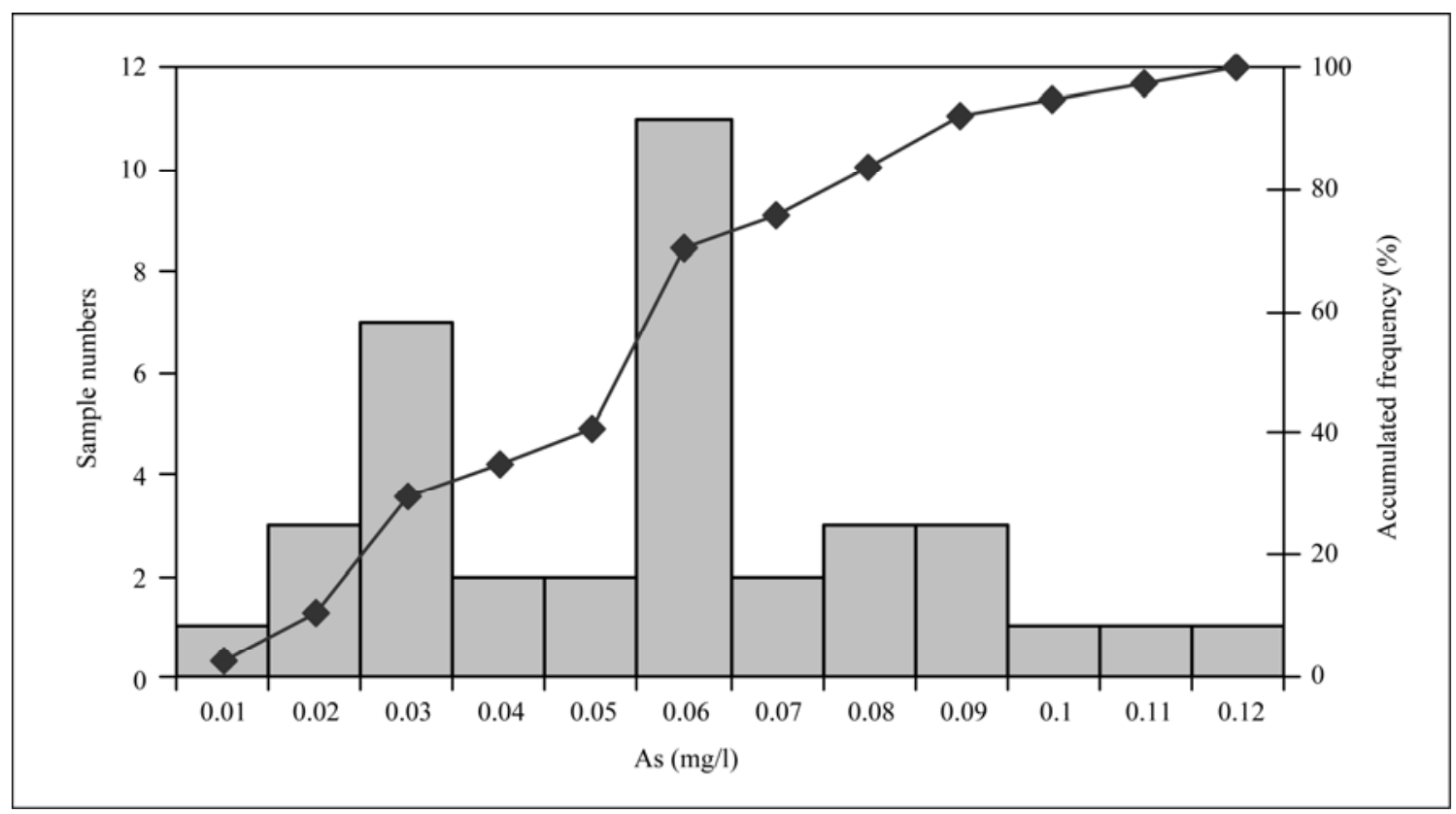

Figure 3. Distribution of accumulated frequencies of arsenic concentrations in groundwater.

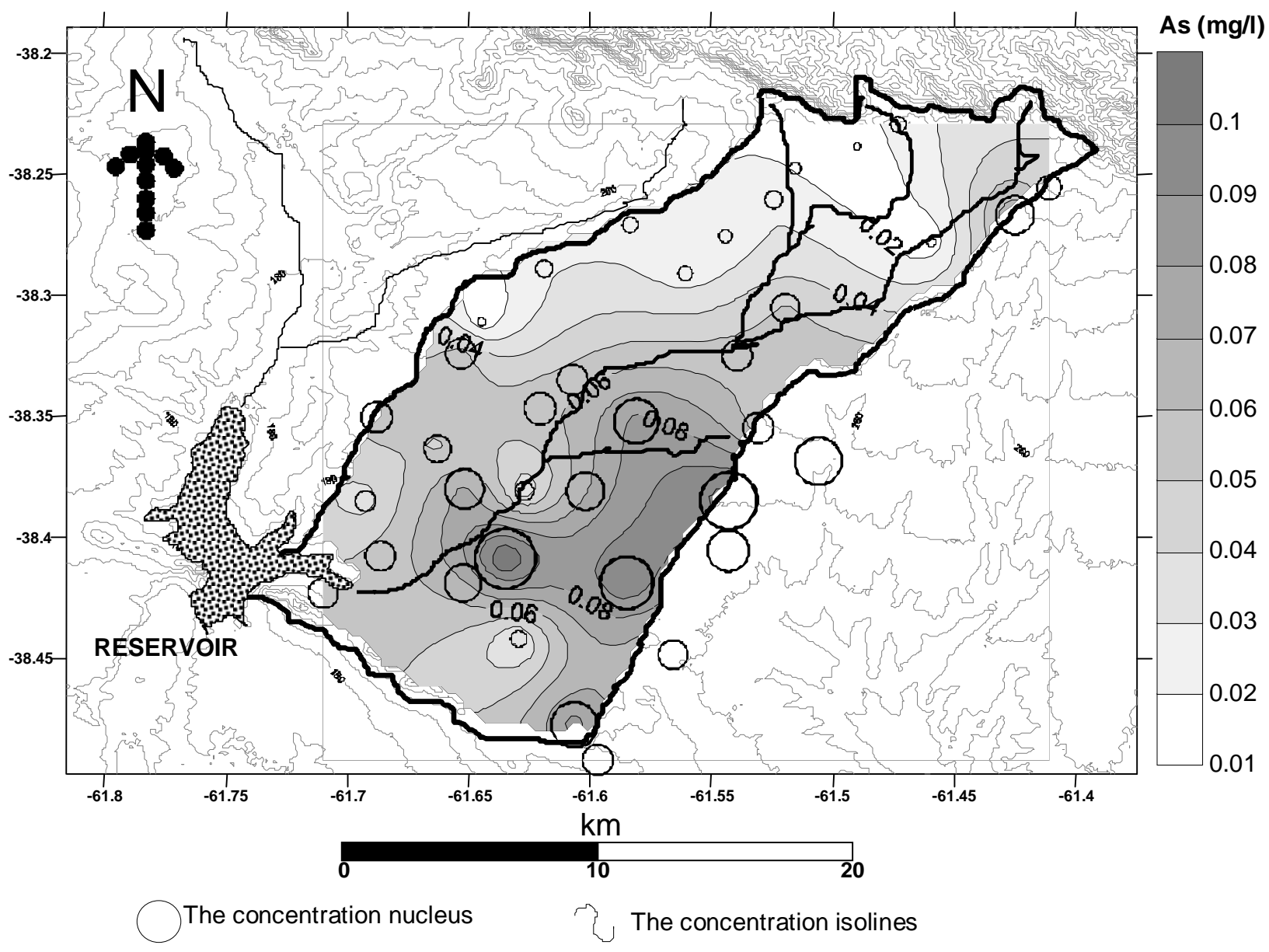

Figure 4. Map of isoconcentration and distribution of arsenic in groundwater. 


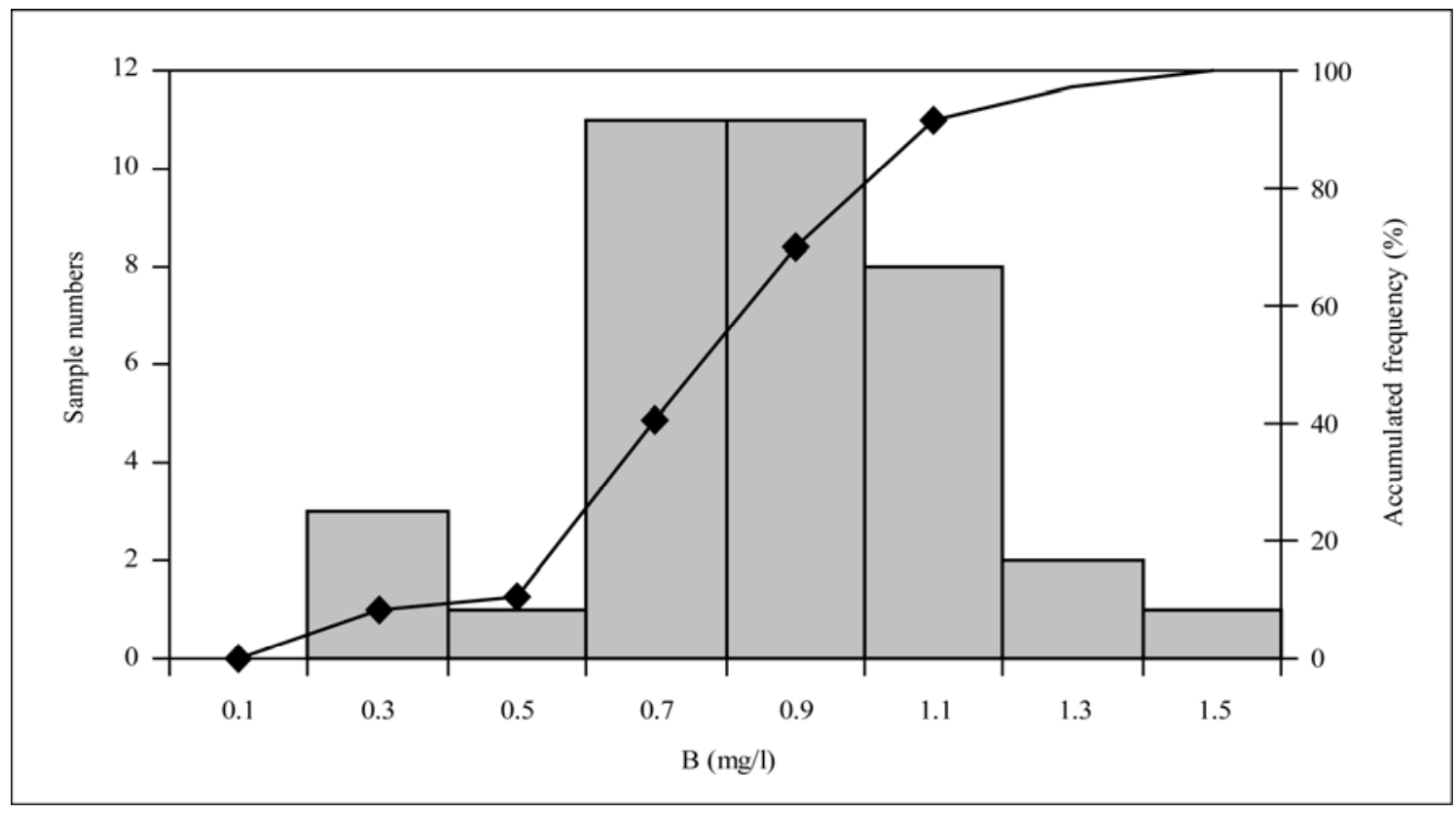

Figure 5. Distribution of accumulated frequencies of boron concentrations in groundwater.

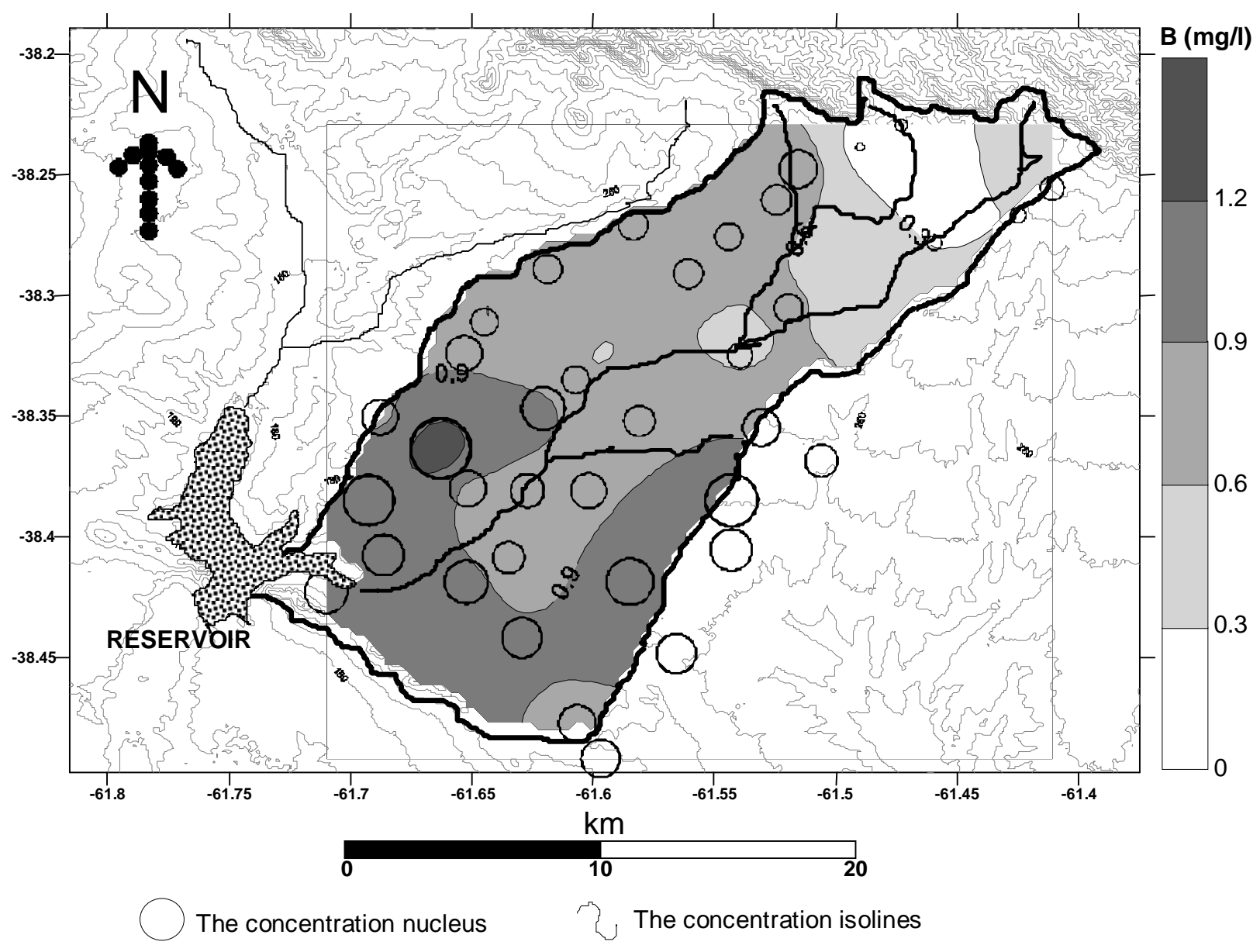

Figure 6. Map of isoconcentration and distribution of boron in the phreatic layer. 
Regarding fluorine, the samples in the groundwater flow showed concentration levels higher than the guideline value in 25 of the analyzed points, presenting an asymmetric and irregular frequency distribution (Figure 7) and being located in the southwest of the middle sector of the basin, as reflected by the morphology of the concentration isolines (Figure 8). Superficial waters showed a smaller proportion of points beyond the limit. Only 2 samples exceed it, the highest concentration level being located at the same point where the maximum concentration of boron was detected. Fluorine concentrations in the basin range from $0.2 \mathrm{mg} / \mathrm{l}$, the lowest record, which belongs to the same sample where the lowest concentrations of the abovementioned elements were found, to the highest value with a magnitude of $6.6 \mathrm{mg} / \mathrm{l}$, located in the middle sector of the study area.

As for vanadium, the results of groundwater analyses proved that it is contaminated in 33 of the collected samples. A complex distribution of frequencies and an asymmetric distribution of the variable concentration (Figure 9) were also observed. Zones with higher content of the contaminant ion are emphasized in the southeast of the middle sector of the basin (Figure 10). In the superficial water resource, this element is present in 8 out of the total number of determinations and its concentration increases from the headwaters towards the mouth. Vanadium values in the study area vary between 0.04 $\mathrm{mg} / \mathrm{l}$ for a sample obtained from a bed of a tributary at the catchment and $0.80 \mathrm{mg} / \mathrm{l}$ in a sector of the middle basin.
Analyzing the variability of ions concentration data matrix showed in the graph of the first two Principal Components (Figure 11), the upper right quadrant (quadrant I) illustrates the samples with the highest concentration of boron and fluorine in the middle and lower basins. The high contents of arsenic and vanadium located in the lower right quadrant (quadrant IV) belong mainly to the middle basin. It is worth noticing that the middle basin presents a clear heterogeneity regarding the chemical composition of the waters since their values are distributed in the four quadrants. Unlike the previously described quadrants, the left sector (quadrants II and III) exhibits values with the lowest concentrations of all the analyzed elements are located, which indicates a better quality of the water belonging mainly to the upper basin, partly to the middle basin and in very few cases to the lower basin.

\section{Conclusions}

Groundwaters had arsenic (max. $0.114 \mathrm{mg} / \mathrm{l}$ ) exceeding the reference guideline in $97.3 \%$ of the samples. Similar values were found for boron (max. $1.42 \mathrm{mg} / \mathrm{l}$ ), vanadium (max. $0.8 \mathrm{mg} / \mathrm{l}$ ) and fluorine (max. $6.6 \mathrm{mg} / \mathrm{l}$ ), respecttively, $91.9 \%, 82.9 \%$, and $67.6 \%$. Regarding the superficial flow, while arsenic concentrations were higher than the limit in $100 \%$ of the cases (max. $0.072 \mathrm{mg} / \mathrm{l}$ ), 88.9\% corresponded to elevated boron (max. $1 \mathrm{mg} / \mathrm{l}$ ) and vanadium (max. $0.23 \mathrm{mg} / \mathrm{l}$ ) and only $22.2 \%$ to fluorine (max. $3.18 \mathrm{mg} / \mathrm{l}$ ) ones. According to obtained results, the hydrochemical characteristics of the basin could determine

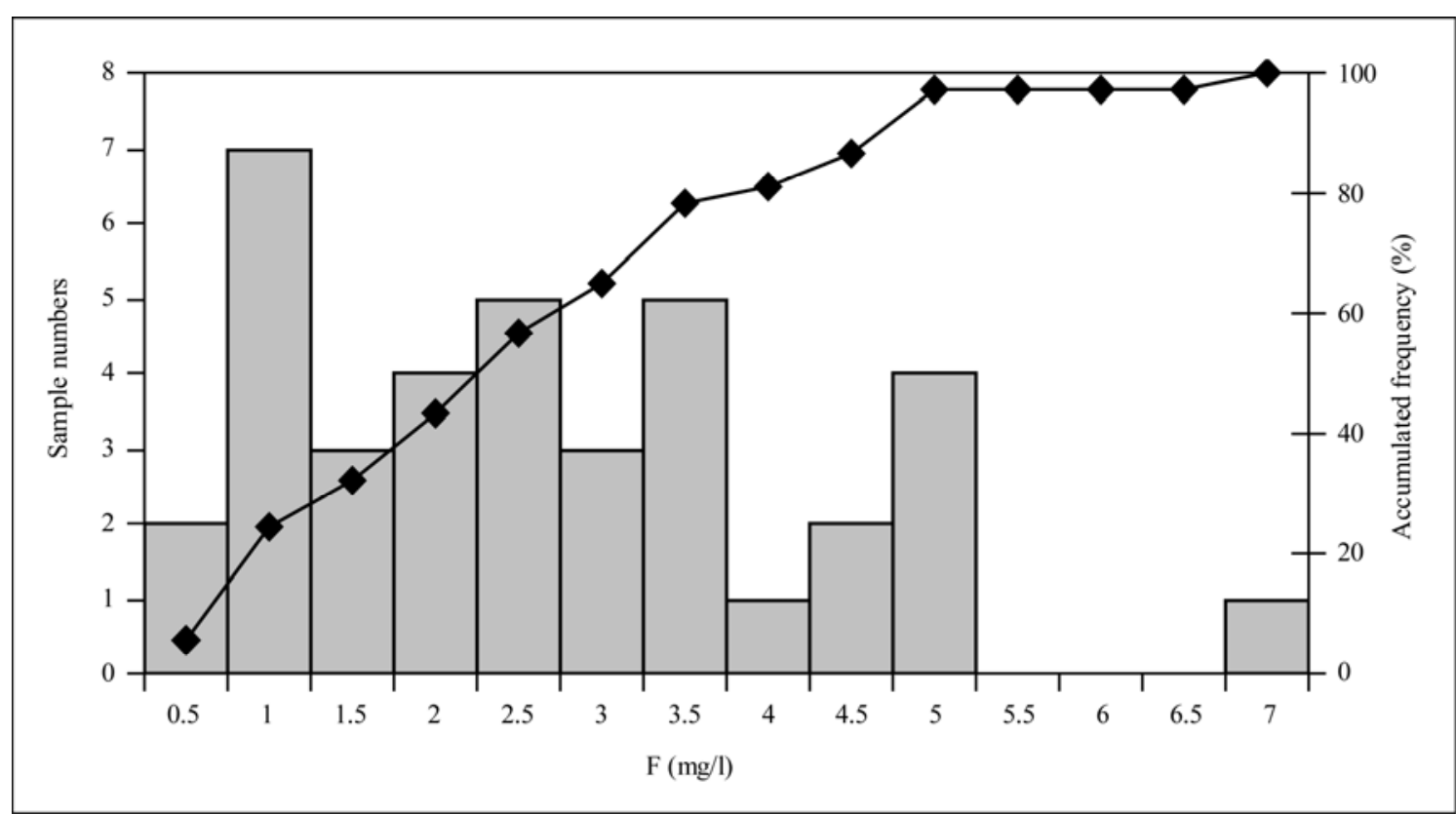

Figure 7. Distribution of accumulated frequencies of fluorine concentrations in groundwater. 


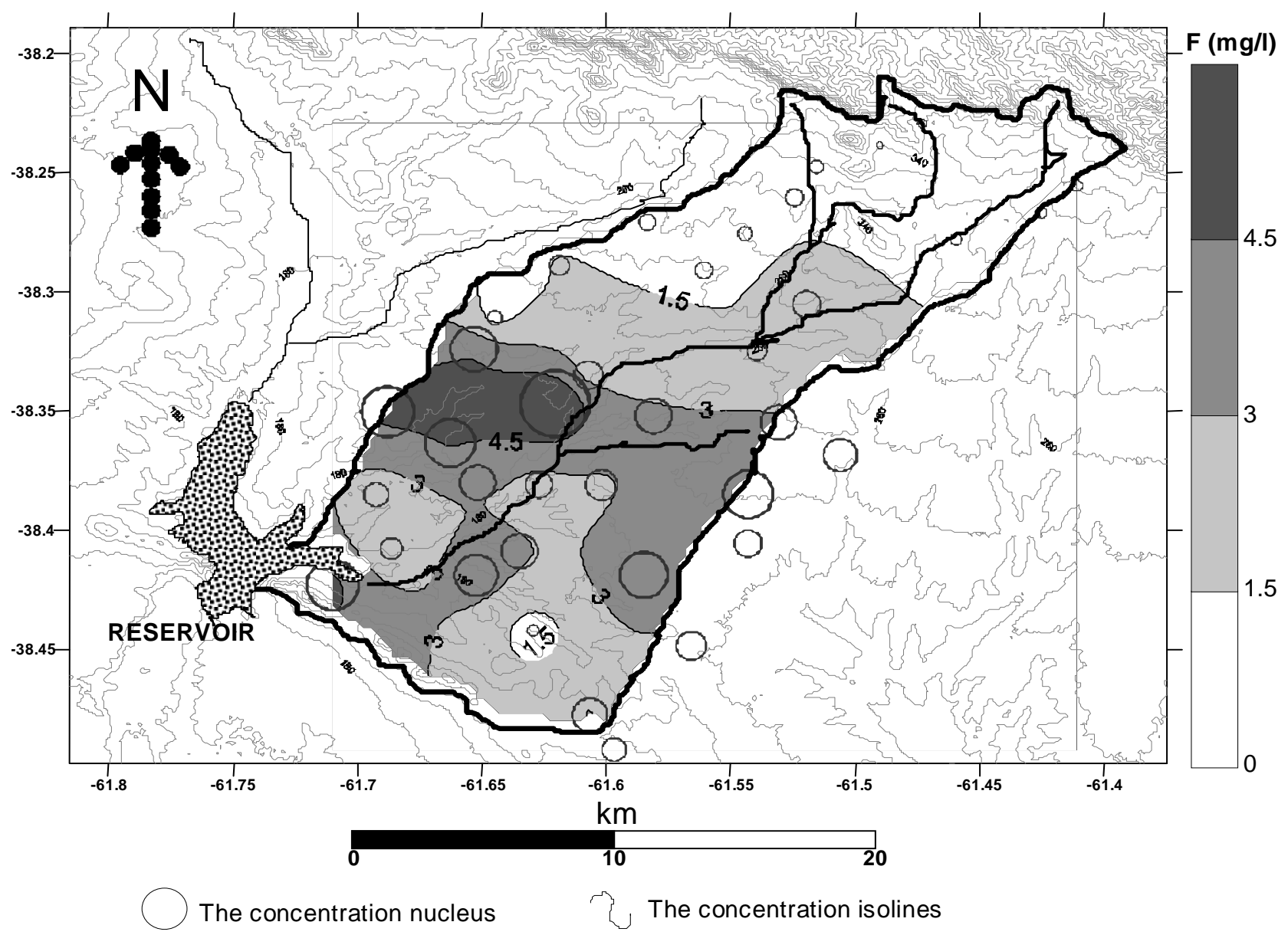

Figure 8. Map of isoconcentration and distribution of fluorine in the groundwater aquifer.

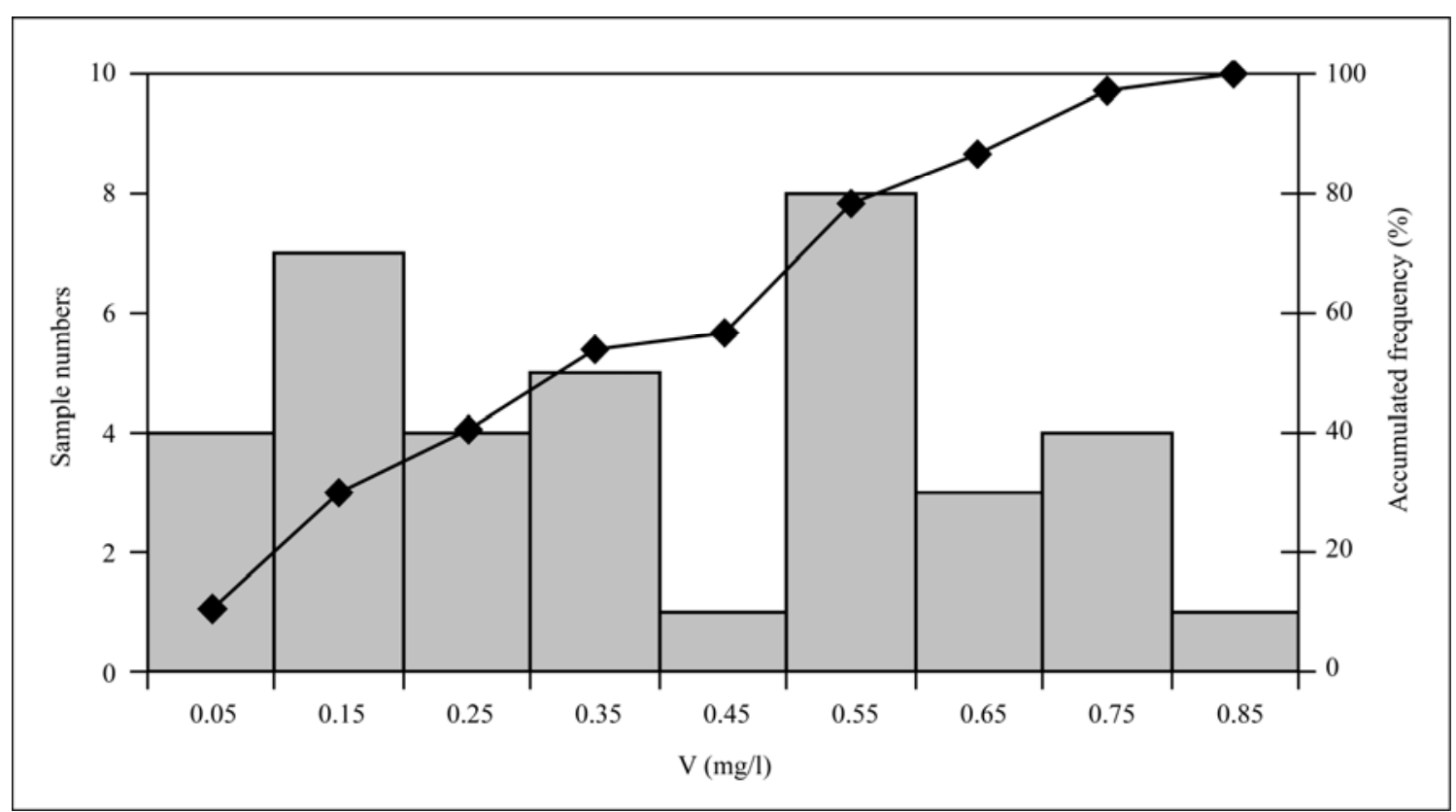

Figure 9. Distribution of accumulated frequencies of vanadium concentrations in groundwater. 


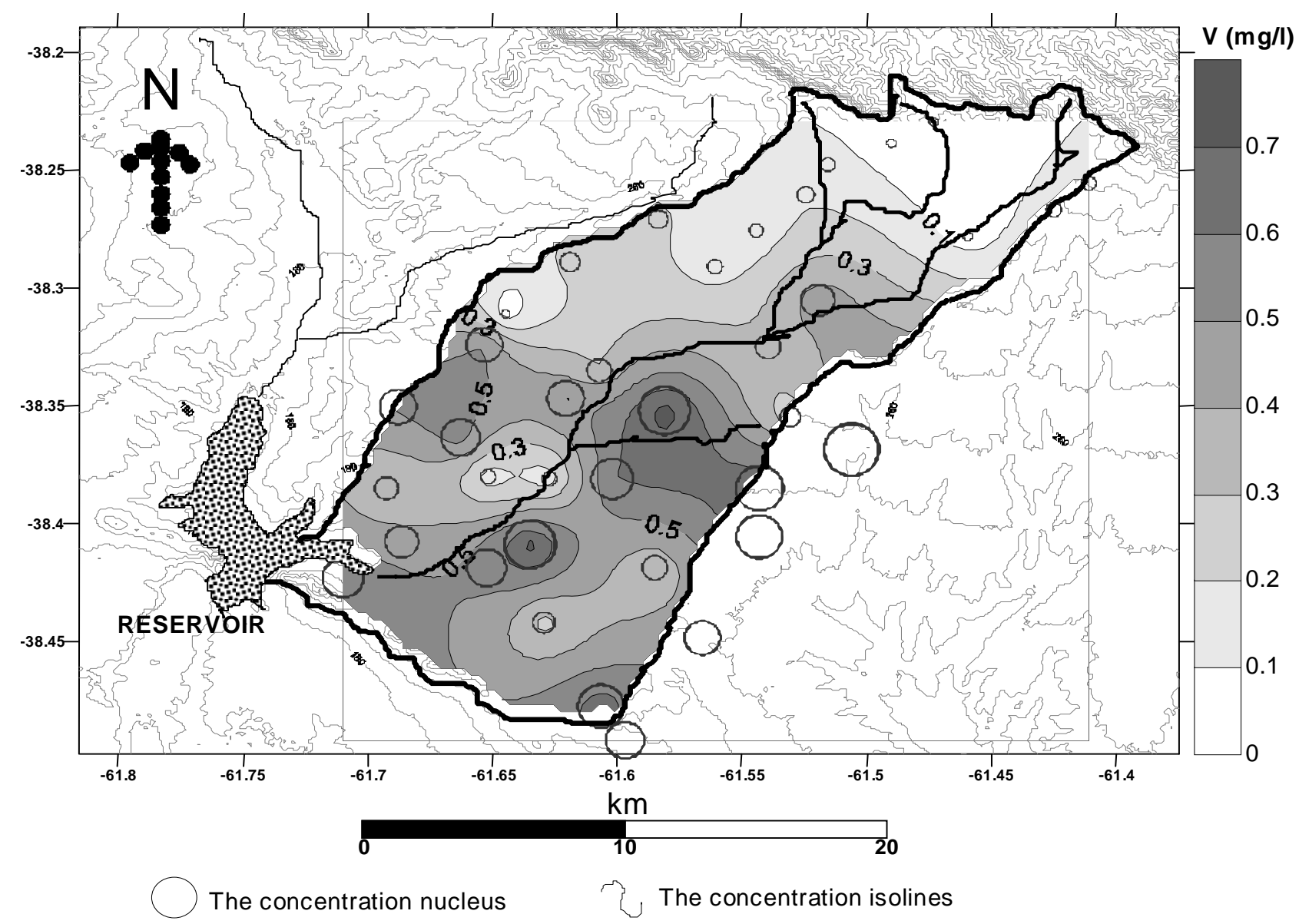

Figure 10. Map of isoconcentration and distribution of vanadium in groundwater.

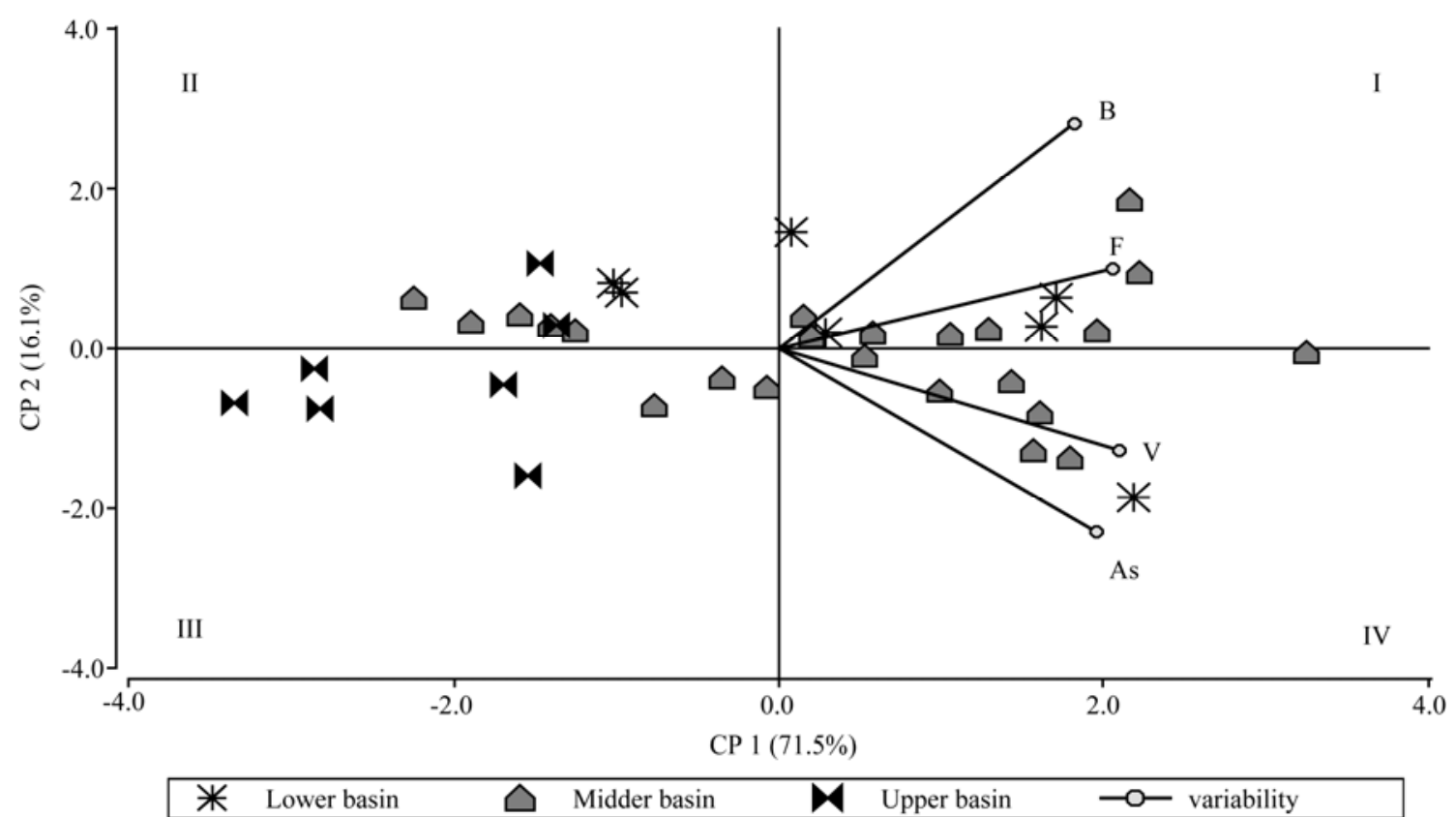

Figure 11. BIPLOT graph of the first two Principal Components. 
the water quality of the reservoir due to the observed degree of concentration of natural contaminants.

The PCA of the four chemical variables under study indicates that the upper basin is not affected by high concentrations of these elements. On the contrary, the points containing the highest arsenic, boron, fluorine and vanadium values were detected in the lower and middle basins.

In addition, considering the evaluation of land utilization and the technology adopted in the production systems in the studied area, the high contents of these contaminants in the water resources may not be ascribed to anthropic actions.

Mapping of contaminants highlighted the areas at the highest risk. Maps are proposed as a simple tool to easily understand the interpretation of our results not only for professionals who practise preventive medicine but also to the community and authorities related to water management, in view of their responsibility for delivery and distribution of drinking water to urban areas.

\section{REFERENCES}

[1] G. Jolánkai and G. Janauer, "Ecohydrogogy a New Paradigm for the Sustainable Use of Aquatic Resources," In: M. Zalewski, G. A. Janauer, G. Jolánkai, IHP-V, Eds., Technical Documents in Hydrology, UNESCO, No. 7, 1997, pp. 37-52.

[2] OMS (Organización Mundial de la Salud), "Guías para la Calidad del Agua Potable,” 2 da. Edición, Vol. 1, Recomendaciones, Ginebra, 1995, pp. 43-45,

[3] "Código Alimentario para Uso de Agua Potable en Argentina,” Cap. XII, Art. 982 (Res. Conj SPRyRS y SAGPyA No 68/2007 y No 196/2007), Buenos Aires, 2007.

[4] U.S. EPA (U.S Envirommental Protection Agency), "Integrated Risk Information System-Online,” Cincinnati, Ohio, Criteria and Assessment office, En: IPCS (Integrated Programme on Chemical Safety) 1998. Enviromental Health Criteria 204. Boron, World Health Organization, Geneva, 1994.

[5] J. Szymanska and J. Cchemielmika, "Health Effects of Exposure of Human to Inorganic Arsenic Compunds," Medycyna Pracy, Vol. 42, No. 3, 1991, pp. 199-206.

[6] J. Ng, J. Wang, A. Shraim, "A Global Health Problem Caused by Arsenic from Natural Sources," Chemosphere, Vol. 52, 2003, pp. 1353-1359.

[7] J. Hindmarsh, O. R. Mc Letchie, L. P. Heffemay, O. Hayne, H. A. Elenberger, R. F. Mc Curd and H. J. Thiebaux, "Electromiographic Abnormalities in Chronic Environmental Arsenicalism," Journal of Analytical Toxicology, Vol. 1, No. 6, 1977, pp. 287-293.

[8] H. Nicolli, P. Smedley and J. Tullio, “Aguas Subterráneas con Altos Contenidos de Flúor, Arsénico y otros Oligoelementos en el Norte de la Provincia de La Pampa; Estudio preliminar," Congreso Internacional de Aguas sobre Química Ambiental y Salud, Libro de Resúmenes, III-3, 1989, pp. 1.

[9] J. Christian and C. M. Hopenhayn, "Is Arsenic Metabolism in Exposed Populations Influenced by Selenium,” Epidemiology, Vol. 4, 2004, pp. 107-109.

[10] UNEP, "Summary, Conclusions and Recommendations, Environmental Health Criteria, Boron,” Environmental Plublications, No. 204, 1998, pp 192-200.

[11] Subsecretaría de Recursos Hídricos de la Nación, República Argentina, "Desarrollos de Niveles Guía Nacionales de Calidad de Agua Ambiente Correspondiente a Boro," Diciembre 2003.

[12] K. Rankama, T. G. Sahama, "Gequímica,” 2 da. Edición, Ediciones Aguilar, S.A., Málaga, España, 1962, pp. 703715.

[13] M. de la Sota, R. Puche, A. Rigalli, L. M. Fernandez, S. Bensatti and R. Boland, "Modificaciones en la Masa Ósea y en la Homeostasis de la Glucosa en Residentes en la Zona de Bahía Blanca con la Alta Ingesta Espontánea de Flúor,” Medicina No. 57, Argentina, 1997 pp. 417-420.

[14] M. G. García, K. L. Lecomte, J. O. Martínez, S. M. Formica and J. P. Depetris, "Flúor en Aguas de Ríos de las Sierras de Cordoba, Argentina," $1^{\circ}$ Congreso Internacional Sobre Gestión y Tratamiento Integral del Agua, Cordoba, Argentina, Abril, 2006.

[15] WHO (World Health Organization), "Guidelines for Drinking Water Quality,” 3rd Ed., Vol. 1, Recommendations, WHO, Geneva, Switzerland, 2004.

[16] N. Avila Carreras, S. Farías and G. Bianco, "Determinación de Fluoruro en Aguas de Rinconadillas,” Acta Toxicológica Argentina, Vol. 16, No. 1, 2008, pp. 14-20.

[17] G. Lagerkvist, G. Nordberb and V. Vouk, "Vanadium,” In: Handbook on the Toxicology of Metal, Elsevier Science Publishing, Amsterdam, 1986, pp 638-663.

[18] EFSA (European Food Safety Authority), “Opinion of the Scientific Panel on Dietetic Products, Nutrition and Allergies on a Request from the Commission Related to the Tolerable Upper Intake Level of Vanadium,” Vol. 33, 2004, pp. 1-22.

[19] B. Mukherjjee, B. Patra, S. Mahapatra, P. Banerjee, A. Tiwari and M. Chatterjee, "Vanadium-An Element of Atypical Biological Significance,” Toxicology Letters, Vol. 150, No. 2, 2004, pp. 135-143.

[20] L. Alessio, M. Marinoni and A. Dell’Orto, "Biological Monitoring of Vanadium,” In: W. T. Clarkson, L. Friberg, F. Nordberg y R. Sanger, Eds., Biological Monitoring of Toxic Metals. Plenum Press, Nueva York, 1988, pp. 427-436.

[21] R. J. French and J. H. Jones, "Role of Vanadium in Nutrition: Metabolism, Essentiality and Dietary Considerations,” Life Sciences, Vol. 52, No. 4, 1993, pp. 339-346.

[22] W. Y. Bal and K. S. Kasprzak, "Induction of Oxidative DNA Damage by Carcinogenic Metals,” Toxicology Letters, Vol. 127, No. 1-3, 2002, pp. 55-62.

[23] IARC (International Agency for Research on Cancer), 
"Monographs on the Evaluation of Carcinogenic Risk to Humans. Cobalt in Hard-Metals and Cobalt Sulfate, Gallium Arsenide, Indium Phosphide and Vanadium Pentoxide,” Vol. 86, Lyon, 2006.

[24] H. B. Nicolli, A. Tineo, J. W. Garcia, C. M. Falcón, M. H. Merino, "Origin and Mobility of Arsenic in Groundwater from the Pampean Plain, Argentina," Water Rock Interaction Report, 2001, pp. 275-278.

[25] H. Morrás, M. C. Blanco and J. D. Paoloni, “Algunas Observaciones Sobre el Origen del Arsénico en Sedimentos, Suelos y Aguas de la Región Chaco-Pampeana, Argentina,” II Taller Sedimentología y Medio Ambiente, Buenos Aires, 28-30 Noviembre 2002, pp. 37-38.

[26] J. L. Fernandez Turiel, G. Galindo, M. A. Parada, D. Gimeno, M. García Vallés and J. Saavedra, "Estado Actual del Conocimiento Sobre el Arsénico en el Agua de Argentina y Chile: Origen, Movilidad y Tratamiento,” II Seminario Hispano-Latinoamericano sobre temas actuales de Hidrología Subterránea. IV Congreso Hidrogeológico Argentino, Río Cuarto, 25-28 Octubre 2005, pp. $1-22$.

[27] P. Blanes and M. C. Jiménez, “Arsénico y otros Oligoelementos Asociados en la Dorsal Agrícola Central de la Pcia. del Chaco,” II Taller sobre arsénico en aguas en III Seminario Hispano-Latinoamericano sobre Temas Actales de Hidrología Subterránea. V Congreso Hidrogeológico Argentino, Paraná, 16-19 de octubre 2007, pp. 61-68.

[28] M del C. Blanco, C. E. Fiorentino, J. D. Paoloni, M. E. Sequeira and M. E. Espósito, "Litologías y Calidad de Aguas Superficiales y Subterráneas: Incidencia en el Hidroarsenicismo de la Región Pampeana Sur,” II Taller sobre arsénico en aguas en el III Seminario HispanoLatinoamericano sobre Temas Actuales de Hidro- logía Subterránea. V Congreso Hidrogeológico Argentino, Paraná, 16-19 de Octubre 2007, pp. 93-98.

[29] M. Gonzalez Uriarte, “Características Geomorfológicas de la Porción Continental que Rodea la Bahía Blanca, Provincia de Buenos Aires,” Congreso Geológico Argentino, S. C. de Bariloche, Actas III, No. 9, 1984, pp. 556576.

[30] J. A. Luque, J. D. Paoloni and G. A. Bonorino, "Estudio Hidrológico e Hidrogeológico de la Cuenca del Río Sauce Grande,” Publicación interna de los Dptos. de Cs. Agrarias y Cs. Naturales, Universidad Nacional del Sur, Serie Hidrológica, No. 3, 1979, pp. 1-64.

[31] M. E. Espósito, M. E. Sequeira, J. D. Paoloni, and N. M. Amiotti, “Análisis Morfométrico de la Cuenca Endorreica de El Divisorio, Sudoeste de la Provincia de Buenos Aires,” V Jornadas Interdisciplinarias del Sudoeste Bonaerenses: Ambiente y recursos naturales del suboeste bonaerense: Producción, contaminación y conservación, Bahía Blanca, 20-22 de agosto2008, pp. 17-29.

[32] J. D. Paoloni, R. Vazquez and C. E. Fiorentino, "La topografía y la Variación de las Precipitaciones y los Escurrimientos en el Sistema de Ventania,” Actas de las 2das, Jornadas Geológicas Bonaerenses, 1988, pp. 651-661.

[33] M. A. Aduriz, A. O. Gargano, P. Chimeno, M. C. Saldungaray and V. P. Conti, "Caracterización de Los Agrosistemas Predominantes de la Cuenca Alta del Río Sauce Grande,” INTA-Revista RIA, Vol. 32, No. 3, Diciembre de 2003, Artículo 1. www.inta.gov.ar/ediciones/ria/32_3/art1.htm-12k 